\title{
Pertinence of nutriments for a stalwart body
}

\author{
Rajwinder Kaur ${ }^{1}$ - Ankita Sood ${ }^{1}$ - Muskan Kanotra ${ }^{1}$ - Sandeep Arora ${ }^{1} \cdot$ Vetriselvan Subramaniyan $^{2}$. \\ Saurabh Bhatia ${ }^{3,4}$. Ahmed Al-Harrasi ${ }^{4} \cdot$ Lotfi Aleya $^{5} \cdot$ Tapan Behl $^{1}$ (I)
}

Received: 16 June 2021 / Accepted: 16 August 2021 / Published online: 26 August 2021

(C) The Author(s), under exclusive licence to Springer-Verlag GmbH Germany, part of Springer Nature 2021

\begin{abstract}
Nutrition plays a significant role in the prevention and treatment of common diseases. Some superb dietary choices such as functional foods and nutriments can surely help fight against certain diseases and provide various advantages to an individual's health. Plants have been regarded as a primary source of highly effective conventional drugs leading to the development of potential novel agents, which may boost the treatment. Growing demand for functional foods acts as an aid for the producers to expand in agriculture and pave the way for innovation and research by the nutraceutical industry. The given review highlights how various functional foods such as tomatoes, chocolates, garlic and flaxseed are currently being defined, their sources, benefit in treating various ailments and the challenges with their use.
\end{abstract}

Keywords Functional foods $\cdot$ Nutriments $\cdot$ Antioxidants $\cdot$ Phytochemicals $\cdot$ Nutraceuticals

\section{Introduction}

The definition of functional foods is not limited; hence, there is no universally accepted definition for it. The notion of the application of functional foods goes back to the 1980s in Japan. Due to the elevating costs in medical management, the Ministry of Health and Welfare commenced proper regulations to use specific foods that provide medicinal benefits and boost patients' health suffering from various ailments (Arai 1996). Functional foods have been defined as whole,

Rajwinder Kaur, Ankita Sood, Muskan Kanotra and Tapan Behl contributed equally to this work.

Responsible Editor: Philippe Garrigues

Tapan Behl

tapanbehl31@gmail.com

1 Chitkara College of Pharmacy, Chitkara University, Rajpura, Punjab, India

2 Faculty of Medicine, Bioscience and Nursing, MAHSA University, Jenjarom, Malaysia

3 Amity Institute of Pharmacy, Amity University, Gurugram, Haryana, India

4 Natural \& Medical Sciences Research Centre, University of Nizwa, Birkat Al Mauz, Nizwa, Oman

5 Chrono-Environment Laboratory, UMR CNRS 6249, Bourgogne Franche-Comté University, Besançon, France fortified, enhanced and enriched food by the American Dietetic Association. They are considered part of the diet on an unvarying basis at efficacious levels (Thomson et al. 1999). In 1999, the Foundation for Innovation in Medicine used the term "nutraceuticals" for the first time, and this term can be used interchangeably with functional foods. Whole foods were differentiated from the isolated components in 1990 by Zeisel, and he had a different definition for nutraceuticals. According to him, nutraceuticals are those diet supplements that deliver a concentrated form of a presumed bioactive agent from a food, presented in a non-food matrix, in dosages that exceed those that could be obtained from regular food (Zeisel 1999).

A majority of the functional foods have multiple therapeutic benefits and have been claimed to have physiological benefits or provide protection against various diseases, as shown in Fig. 1 (Das et al. 2012). Besides, they act as cardiovascular agents, anti-obese agents, anti-diabetic agents, anti-cancer agents, immuno-boosters, substances that manage chronic inflammatory disorders and formulations to cure degenerative diseases (Rajasekaran et al. 2008).

Nutriments also refer to natural functional/medical foods or bioactive phytochemicals with health-promoting, disease-preventing or medicinal properties. These nutriments, in general, contain vitamins, lipids, proteins, carbohydrates, minerals or other necessary nutrients, depending on their emphases (Whitman 2001). 
Fig. 1 Pie chart demonstrating therapeutic benefits provided by the nutriments

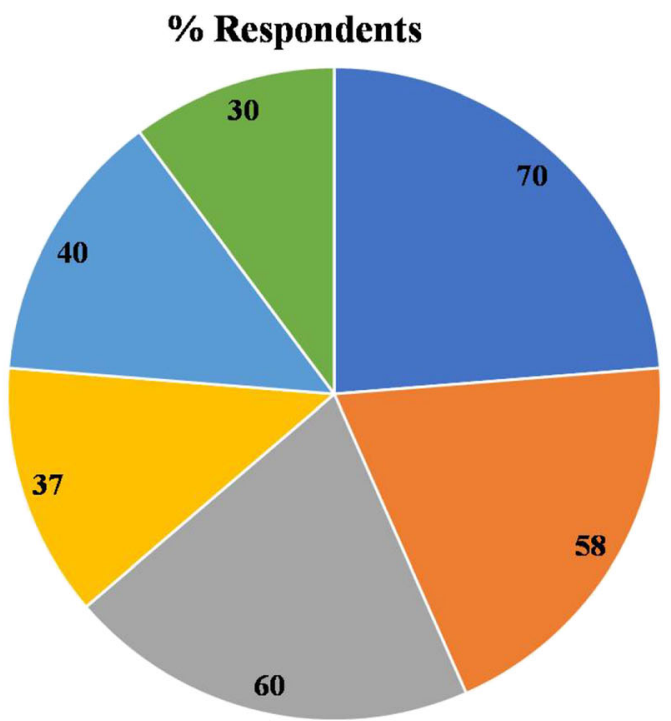

" CVS diseases $"$ cancer $"$ lipid control $"$ osteoporosis $"$ diabetes $"$ hypertension

\section{Functional food}

\section{Significance of functional food}

There are positive effects on the health and well-being of humans due to the use of the traditional Mediterranean diet, which can pave the way for designing functional foods. Vegetables, fruits and nuts are a rich source of bioactive compounds like phenols, flavonoids, isoflavonoids, phytosterols and phytic acid. Fish is a rich source of polyunsaturated fatty acids, responsible for regulating haemostatic factors, protecting against cardiac arrhythmias, cancer and hypertension, and plays a vital role in maintaining neural functions and preventing certain psychiatric disorders (Ortega 2006).

An integral component of the Mediterranean diet, olive oil, has health benefits, including reducing the risk of coronary heart disease, preventing various types of carcinomas and modifying the immune and inflammatory responses. Olive oil is rich in monounsaturated fatty acids and is a good source of phytochemicals, such as polyphenolic compounds, squalene and alpha-tocopherol (Pagliai et al. 2018).

\section{Classification of functional food}

Various active ingredients regulating physiological functions of the body are obtained from plant or animal sources and are beneficial in preventing ailments and providing a relevant cure. However, necessary medical documentation of their significance in healthcare is limited. Many plant-based foods have a strong potential that is not currently being approved for clinical use, but there is a piece of evidence for their health benefits (Khramtsov et al. 2017). The functional foods can be classified into flax seeds, chocolate, broccoli, tomato and many more having excellent therapeutic actions on the various organ systems of the body as depicted in Fig. 2. Each nutriment has its value and pharmacological actions, as mentioned in Table 2 .

\section{Flaxseeds}

Flaxseeds, also known as linseeds, which are dried and ripe, are obtained from Linum usitatissimum. It is cultivated commonly in most of the world, and Canada is the largest cultivator. Lipid profile and blood pressure can be improved due to the administration of flax seeds, which helps treat hypertension and hyperlipidaemia (Haghighatsiar et al. 2019). Flaxseeds are a rich source of omega-3 fatty acid, alphalinolenic acid and fibres (Parikh et al. 2019). Coronary heart disease is a major cause of death worldwide. The composition of flaxseed includes a high concentration of lignans such as secoisolariciresinol diglucoside, fibre and $\alpha$-linolenic acid, which provide cardiovascular protection. A decrease in serum cholesterol levels decreases the incidence of cardiovascular disease. Flaxseeds also have hypoglycaemic effects, which can help in the prevention of diabetes mellitus. Flaxseeds have high arginine content, due to which they exhibit antihypertensive properties and maintain blood pressure. Besides, flaxseeds also possess antioxidant and antiinflammatory properties.

Flaxseeds show cholesterol-lowering properties hence reducing the levels of LDL and total serum cholesterol (Haghighatsiar et al. 2019). They can be consumed in whole flaxseed, ground flaxseed, flaxseed oil and partially defatted flaxseed. They can also be consumed in the form of flax milk 
Fig. 2 Action of essential nutriments on various organ systems of the body including cardiovascular, respiratory, nervous, gastrointestinal, hepatic and reproductive systems

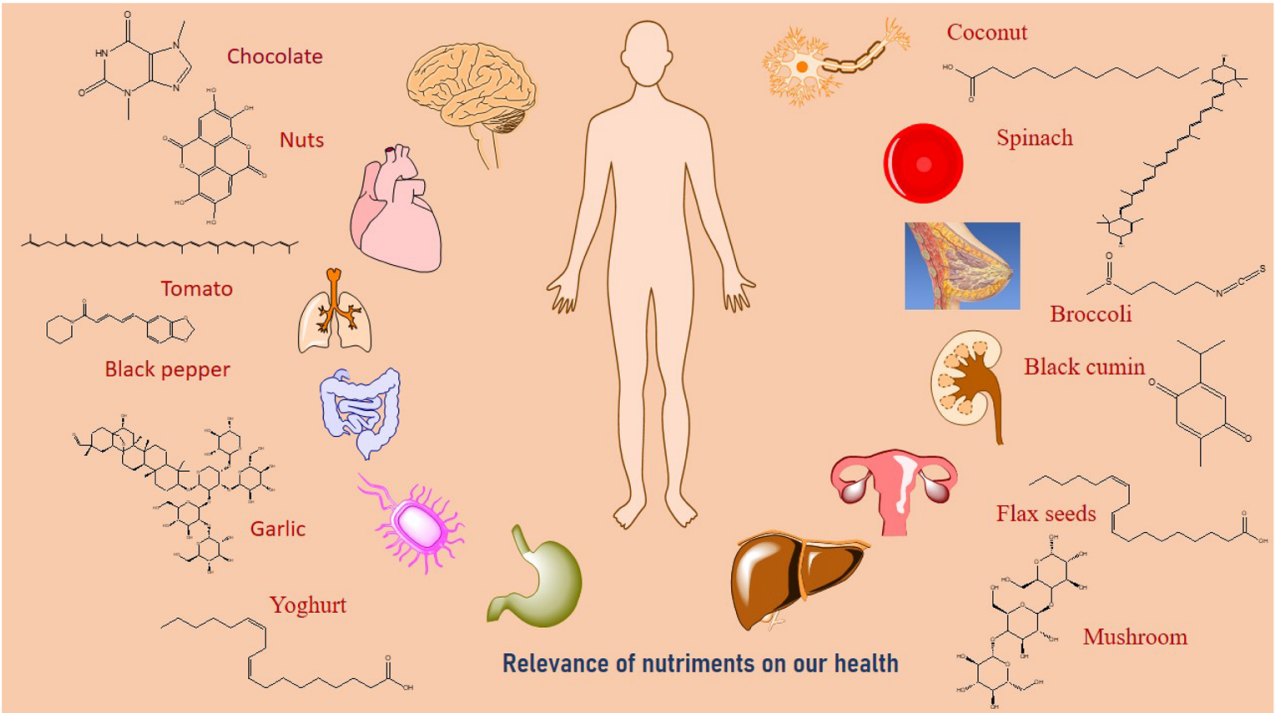

which is cholesterol and lactose-free, and provides health benefits and suitable for people who are allergic to soy, gluten and nuts. It can be incorporated into other food items, including muffins, biscuits, buns, rolls and pasta, to enhance the flavour. The presence of phytic acids, linatine and cyanogenic glycosides in flaxseeds can alter the bioavailability of various essential nutrients. They are of significance to breast cancer patients as it reduces tumor growth and mortality (Chishty and Bissu 2016).<smiles>CC/C=C/C/C=C/C/C=C/CCCCCCCC(=O)OCCCCC/C=C/C/C=C/CCCCCCCC(=O)O</smiles>

Linolenic acid<smiles>CC/C=C\C/C=C\C/C=C\C/C=C\C/C=C\C/C=C\CCC(=O)O</smiles>

Docosahexaenoic acid<smiles>COc1cc(CC(CO[C@H]2O[C@H](CO)[C@@H](O)[C@H](O)[C@H]2O)C(CO[C@H]2O[C@H](CO)[C@@H](O)[C@H](O)[C@H]2O)Cc2ccc(O)c(OC)c2)ccc1O</smiles>

Linoleic acid<smiles>CC/C=C\C/C=C\C/C=C\C/C=C\C/C=C\CCCC(=O)O</smiles>

Eicosapentaenoic acid

Secoisolariciresinol diglucoside

\section{Chemical constituents of flax seeds}

The chemical structure of flaxseed lignans is similar to mammalian oestrogen and is responsible for oestrogen-like effects. Besides being effective in breast cancer, flaxseeds are also beneficial in prostate, lung, ovarian and endometrium cancer due to the presence of $\alpha$-linolenic acid and secoisolariciresinol diglucoside. They are protective in cancer because they inhibit cellular proliferation, angiogenesis, metastasis and inflammation (Kajla et al. 2015). Omega-3 fatty acids docosahexaenoic acid and eicosapentaenoic acid have an essential role in brain development and memory. Flaxseeds 
also have a beneficial role in the management of menopausal symptoms and prevent the severity of hot flashes. However, it is advised to be taken cautiously during pregnancy and lactation (Goyal et al. 2014). Tartrate-resistant acid phosphatase, a bone resorption marker, was decreased in postmenopausal women who were administered flaxseed. Administration of flax oil can prevent the incidence of alcoholic liver disease by reducing the presence of Proteobacteria and Porphyromonadaceae (Parikh et al. 2019). Flaxseeds are known to be beneficial in a condition called PCOS (polycystic ovarian syndrome), an endocrine disorder of women. Flaxseeds in combination with lifestyle modification were able to reduce weight and insulin concentration and improved menstrual cycle (Haidari et al. 2020). Supplementations of flax seeds result in a remarkable deduction in ovarian volume and the number of follicles in polycystic ovaries. Frequency improvement of a menstrual cycle is observed. Not only this, but it does not produce changes in body weight, body sugar and also hirsutism. These positive outcomes of FSP recorded could be due to reduction in testosterone, oestrogen, LH and insulin levels contributing to follicular maturation and the anti-inflammatory actions to the reduction in ovarian volume. Flax seeds can be used as an alternative source for future drug development for PCOS by observing the continuous improvement in ovarian function and menstrual cycle (Nowak et al. 2007). The clinical status of flaxseeds in PCOS treatment is mentioned in Table 4.

\section{Tomato}

Tomatoes are the edible berry of the plant Solanum lycopersicum. Tomatoes and their supplements are used to benefit the chemoprevention of growth as they are a significant dietary source of carotenoid lycopene (Fan et al. 2018; Story et al. 2010). Lycopene is a nonprovitamin A, which is an intoxicating antioxidant. Giovannucci et al. conducted 72 epidemiologic studies. Fifty-seven studies indicated a reverse connection between intake of tomato or lycopene concentration in plasma and the possibility of developing carcinoma at a particular site of the body. High tomato consumption and lycopene level in blood were not reflected in the studies. There was no unique relationship between tomato consumption and cancer risk. According to the data, people affected with prostate, lung and belly carcinoma received the maximum benefits. Patients suffering from carcinomas of the pancreas, colon and rectum, oesophagus, oral cavity, breast and cervix also received benefits and advantages using tomato as a nutriment (Giovannucci 1999). The red colour of tomato is due to lycopene, and it constitutes a major part of the diet of North Americans and Europeans. Tomato has potential health benefits. $\beta$-Carotene, another carotenoid present in tomato, is known to reduce cancer risk, especially in cancers in which tobacco is the causative agent (Wei and Giovannucci 2012). In an Italian case study, more than seven servings of tomato consumption compared to less than two servings taken per week proved more beneficial and had a $50 \%$ risk reduction. Gastric cancer risk was found to decrease with high serum concentrations of lycopene. By consuming tomatoes, the risk of developing malignancies and polyps of the colon and rectum was found to decrease (Clinton 1998).

\section{Garlic}

Allium sativum is a perennial plant containing compounds sulfur and selenium. Garlic shows antibacterial,<smiles>CC(C)=CCC/C(C)=C/C=C/C(C)=C/C=C/C(C)=C/C=C/C=C(C)/C=C/C=C(C)/C=C/C=C(C)/C=C/C=C(C)/C=C/C=C(C)/C=C/C=C(C)/C=C/C1=C(C)CCCC1(C)C</smiles>

Constituents of tomato

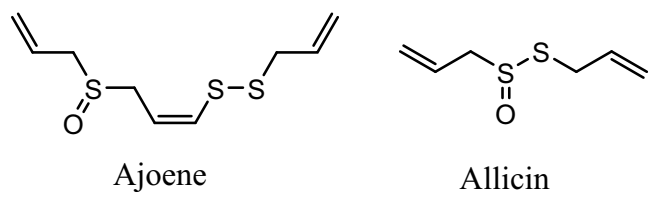

Constituents of garlic

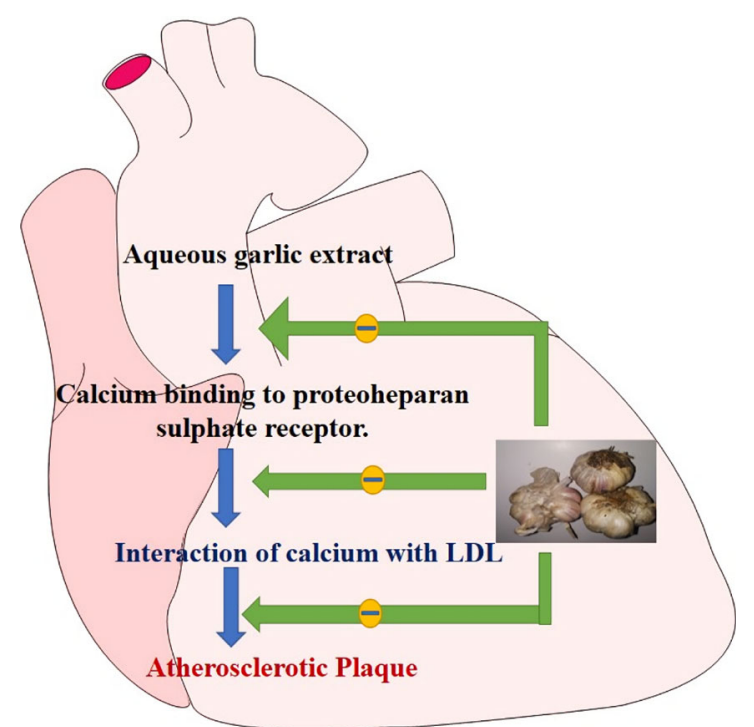

Fig. 3 Role of garlic in inhibition of the atherosclerotic plaque and reduction in the risk of developing cardiovascular disease 
antitumor, antiplatelet, anti-hypertensive and antiasthmatic effects. The prevalence of cancer is decreased due to the consumption of onion and garlic (Suleria et al. 2015). A substantial decrease in gastrointestinal and prostate cancers has been observed with regular and adequate consumption of garlic (Bayan et al. 2014). Garlic possesses an anti-cancer effect due to the presence of selenium. Thiosulfinates are responsible for enzyme inhibition in cancerous cells. Garlic is responsible for increasing glutathione peroxidase and inhibiting the enzyme HMG-CoA reductase and hence inactivating nitrosamines. Conversion of nitrate to nitrite can be inhibited in case of stomach cancers. Nnitrosation is also inhibited due to the formation of $\mathrm{S}$ nitrosothiols or thionitrites and nitric oxide. Allicin is responsible for carrying out apoptosis of cancerous cells and inhibiting their growth. Allicin also triggers the activation of caspases-3, -8 and -9 and cleavage of poly (ADP-ribose) polymerase. The proliferation of cancerous cells of the mammary gland, colon and endometrium is also inhibited by allicin. Ajoene, another organosulfur compound present in garlic, helps in the prevention of skin cancer (Block 2004). Garlic possesses antibacterial activity against E. coli, H. pylori and antifungal activity against Candida albicans. Allicin also shows antipara- sitic activity against Entamoeba histolytica and giardia (Pise et al. 2009). Garlic shows anticoagulation property by blocking the binding of fibrinogen to platelets. Garlic helps in the relaxation of vascular smooth muscles. Garlic shows anti-hyperlipidemic activity by decreasing the formation of fatty streaks. Figure 3 depicts the action of garlic in preventing the formation of atherosclerotic plaque. Aqueous garlic extract inhibits calcium binding to proteoheparan sulphate receptor leading to inhibition of calcium interaction with LDL. The enzyme HMG-CoA reductase is affected, which inhibits the biosynthesis of cholesterol. Garlic shows antioxidant activity by inhibiting nitric oxide production by cytokine-induced NO synthase. T cell functions are regulated by allicin which helps in treating chronic inflammatory diseases (Block 2004). Consumption of garlic also decreases the risk of having nasopharyngeal, colon and endometrial carcinomas (Takezaki et al. 1999). The lipid-lowering effects of garlic have been observed, and it is known to reduce cholesterol levels in the body. Garlic also has other protective effects such as reduction in blood pressure, inhibiting platelet formation in cardiovascular diseases and increased blood flow in the arteries (Stevinson et al. 2000).<smiles>CC(C)=CCC/C(C)=C/C=C/C(C)=C/C=C/C(C)=C/C=C/C=C(C)/C=C/C=C(C)/C=C/C=C(\C)CC/C=C(\C)C(=O)OC(=O)/C=C/C(C)=C/C=C/C(C)=C/C=C/C=C(C)/C=C/C=C(C)/C=C/C1=C(C)CCCC1(C)C</smiles>

$\beta$-Ccarotene

Constituents of tomato<smiles>C=CCSS/C=C\CS(=O)CC=C</smiles>

Ajoene<smiles>C=CCSS(=O)CC=C</smiles>

Allicin

\section{Constituents of garlic}


Fig. 4 Protective role of cocoa in obesity

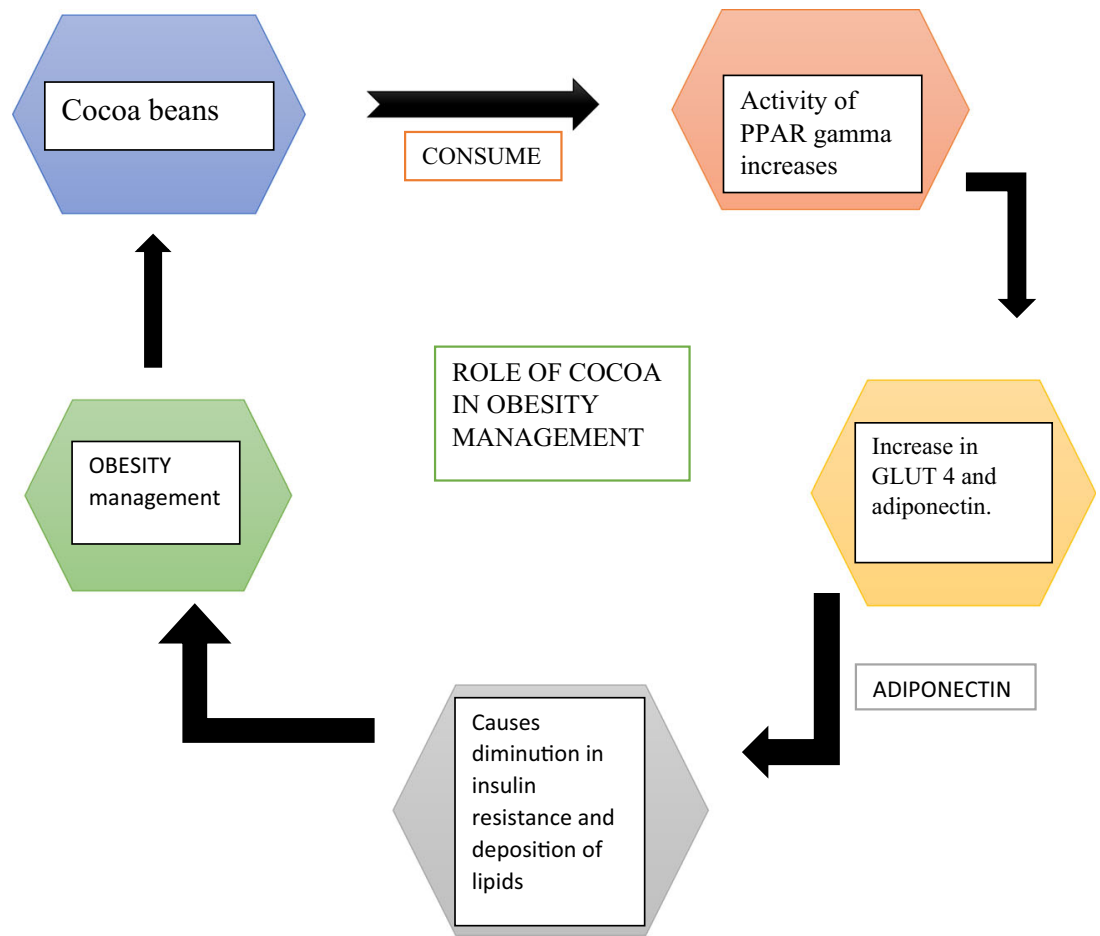

\section{Yoghurt}

Consumption of dairy products such as yoghurt can improve both physical and mental health and improve nutrition-related disorders (Park 2009). Yoghurt consists of nutrients and bioactive components. It is a rich source of proteins, $\alpha \mathrm{S} 1$-casein, $\alpha$ S2-casein, $\beta$-casein, $\mathrm{k}$-casein, $\beta$-lactoglobulin, linoleic acid, inulin and fat, and vitamins such as A, D, B2, B5 and B12, and minerals such as calcium, phosphorus, magnesium, iodine, potassium and zinc. The presence of proteins helps in better digestion with a positive effect on gut microbiota. Yoghurt is beneficial in cardiometabolic diseases such as obesity, diabetes and hypertension. Bone health is also enhanced, and the risk of cancers is reduced (Astrup 2014). Consumption of dairy products such as milk and yoghurt reduces coronary artery disease and cardiovascular disease incidence. Yoghurt can improve symptoms of various metabolic disorders, including obesity, diabetes and hypertension. Yoghurt also possesses probiotic action (Guiné and De Lemos 2020).

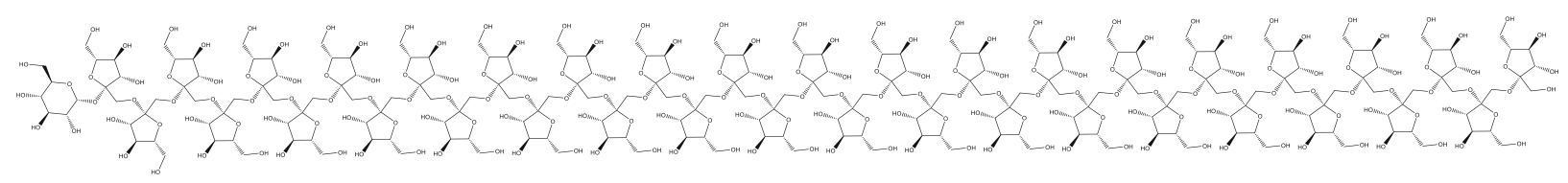

\section{Chocolate}

Chocolate is obtained from roasted seeds of Theobroma cacao L. Cocoas and chocolates are a rich source of flavonoids and polyphenols (https://theconversation.com/a-brief-history-ofchocolate-and-some-of-its-surprising-health-benefits142692)

They possess antioxidant property due to the presence of catechin, procyanidins and theobromine. LDL oxidation is inhibited due to the scavenging of radicals, and the risk of thrombosis is reduced (Smith 2013). Chocolates also exhibit lipoprotein-binding antioxidant property thereby reducing the risk of cardiovascular diseases (Wan et al. 2001). The vascular environment can also be improved due to adequate consumption of cocoa (Erdman et al. 2008). Cocoa can also enhance physical and mental functions. The constituents of cocoa include cocoa butter, minerals, methylxanthines and polyphenols. Neuroprotective and neuromodulatory actions occur due 
to the presence of flavonoids that promote neurogenesis and improve neurons' function. The flow of blood to the brain and sensory systems also increases. Cognition is enhanced, insulin resistance is improved and there is an improvement in antiinflammatory properties. Tryptophan is converted into serotonin which is helpful in the prevention of depression (Mestry et al. 2016). Dark chocolate has a beneficiary role in management of obesity by reducing body weight and body fat. It consists of cocoa flavanols which are known to possess antioxidant properties (Halib et al. 2020). Polyphenols present in dark chocolate decrease fat absorption and fat synthesis. Cocoa aids in glucose and lipid digestion by inhibiting pancreatic enzymes and suppressing early stages of adipogenesis. Dark chocolate reduces cravings due to its intense cocoa flavour (Farhat et al. 2014). Figure 4 depicts the mechanism behind controlling obesity due to consumption of cocoa by attenuating lipid deposition.<smiles>Cn1cnc2c1c(=O)[nH]c(=O)n2C</smiles>

Theobromine

\section{Nuts}

Walnuts are good in reducing cases of cardiovascular diseases. Walnuts are a rich source of polyunsaturated fatty acids, tannins such as ellagic acid and polyphenols. They lower the blood lipid levels (Feldman 2002). Nuts contain 46-76\% of fats and also consist of sterols, vitamins, polyphenols, minerals and antioxidants. Walnuts are composed of omega- 3 and omega- 6 fatty acids. The endothelial function is improved in hypercholesterolemic and diabetic patients. Polyphenols contain antioxidant $\alpha$-tocopherol, which helps in preventing oxidation and hence protects the heart (Bashan and Bakman 2018).

\section{Cranberries}

Vaccinium macrocarpon, also called the American Cranberry, has an amazing history. Cranberry is known to treat urinary tract infections (UTIs) by carrying out urine acidification (https:// www.webmd.com/food-recipes/health-benefits-cranberries). The other mechanism by which cranberries help in treating UTIs is that they inhibit adhesion of the bacteria $E$. coli to uroepithelial cells due to proanthocyanidins (Blumberg et al. 2013). Cranberries also have anti-adhesion properties for urinary pathogens and antioxidant properties (Hisano et al. 2012). The active biological compounds present in the cranberries include xyloglucan oligosaccharides such as arabinoxyloglucan oligosaccharides and pectic oligosaccharides (Gardana et al. 2020). Cranberries maintain gut health and oral health. Cranberries are also used in the treatment of chronic diseases, including diabetes, high cholesterol and cancer. The fermented cranberries maintain epithelial cell health and lower cholesterol. They also reduce secondary bile levels and hence help in the detoxification process (Coleman and Ferreira 2020).

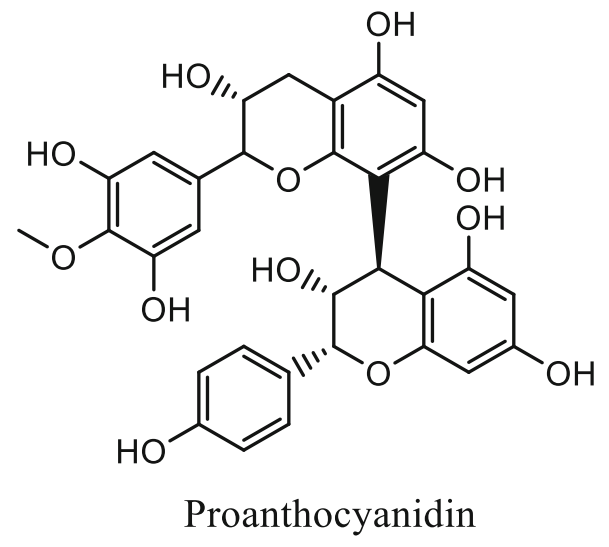

\section{Nigella sativa}

Nigella sativa or black cumin is used as a traditional medicine that belongs to the family Ranunculaceae. Its composition includes essential oils, proteins, thymoquinone, alkaloids, thymohydroquinone, dithymoquinone, p-cymene, $\alpha$-pinene, thymol and saponin. Nigella sativa has antioxidant properties.<smiles>Cc1c(C)c2c(c(C)c1O)CC[C@](C)(CCC[C@H](C)CCC[C@H](C)CCCC(C)C)O2</smiles>

\section{Constituents of nuts}

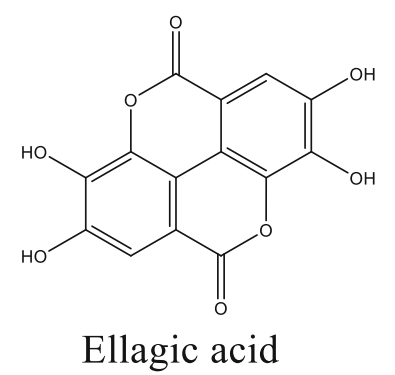


It balances the production of reactive oxygen species and the defence system of the body. It has been traditionally used to treat various ailments, including disorders of the digestive tract, respiratory tract such as asthma and bronchitis, cardiovascular system, immune system, renal disorders and liver disorders (Rahmani and Aly 2015). It is also called a seed of blessing used in treating indigestion, diarrhoea, amenorrhoea and dysmenorrhoea. The oil extracted from the seeds can be used in the treatment of skin disorders as an antiseptic. It is also known to possess antibacterial property against Staphylococcus aureus due to the presence of thymoquinone and melanin. N. sativa also possesses anti $H$. pylori action in patients with non-ulcer dyspepsia. It shows antifungal properties against Candida albicans. It shows efficacy in the prevention of liver damage caused due to Schistosoma mansoni by decreasing the number of worms. A combination of black cumin and praziquantel is efficient in decreasing the ova production by Schistosoma mansoni. Black cumin also possesses anti-diabetic, anti-cancer, antiinflammatory properties, cardiovascular activity, immunomodulatory action, gastro-protective action, nephroprotective action and analgesic activity, and exhibits neuro-pharmacological actions (Rachman and Darmawan 2017; Ahmad et al. 2013)<smiles>Cc1ccc(C(C)C)c(O)c1</smiles>

Thymol<smiles>Cc1ccc(C(C)C)cc1</smiles>

p-Cymene<smiles>CC1=CC(=O)C(C(C)C)=CC1=O</smiles><smiles>Cc1cc(O)c(C(C)C)cc1O</smiles>

Thymohydroquinone

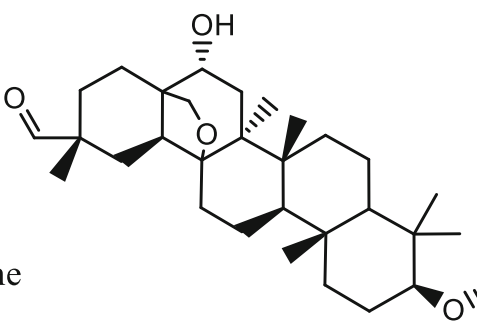

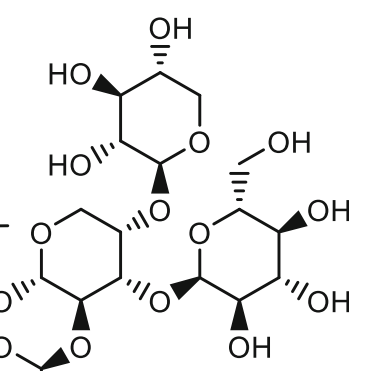<smiles>CC1=CCC2CC1C(C)(C)C2</smiles>

$\alpha$-Pinene<smiles>CO[C@H]1O[C@H](CO)[C@@H](O)[C@H](O)[C@H]1O[C@H]1O[C@H](CO)[C@@H](O)[C@H](O)[C@H]1O</smiles>

Constituents of Nigella sativa

\section{Avocado}

Persea americana or avocado, or gator pear, shows magnificent nutritional and medicinal properties. Its composition includes fats; proteins; fibres; vitamins $\mathrm{C}, \mathrm{E}, \mathrm{K}, \mathrm{B} 1, \mathrm{~B} 2, \mathrm{~B} 6$ and $\mathrm{B} 9$; phosphorus; sodium; magnesium; potassium; zinc; and iron. Due to its low sugar content, it can be consumed by diabetic people as well. Phytochemical constituents present in avocado show anti-cancer properties by activating apoptosis in cancer cell lines. The presence of vitamins $\mathrm{A}$ and B prevents carcinogenesis and inflammation. It is regarded as an essential food by American Dietetic Association (Alkhalaf et al. 2019). Avocados are a rich source of monounsaturated fatty acids, which enhance phytochemical bioavailability. Avocados have a beneficial effect in the management of total cholesterol levels and controlling body weight. Consumption of avocado paves the way for a healthy heart. Avocado is composed of potassium which helps in the management of hypertension. Magnesium present in avocado acts as a cofactor for enzymes necessary for energy metabolism. Lutein and zeaxanthin present in avocado improve eye health. Avocado is also beneficial in the treatment of osteoarthritis and also maintain skin health. Avocados are beneficial in treating cancers of the larynx, pharynx and oral activity (Dreher and Davenport 2013). 


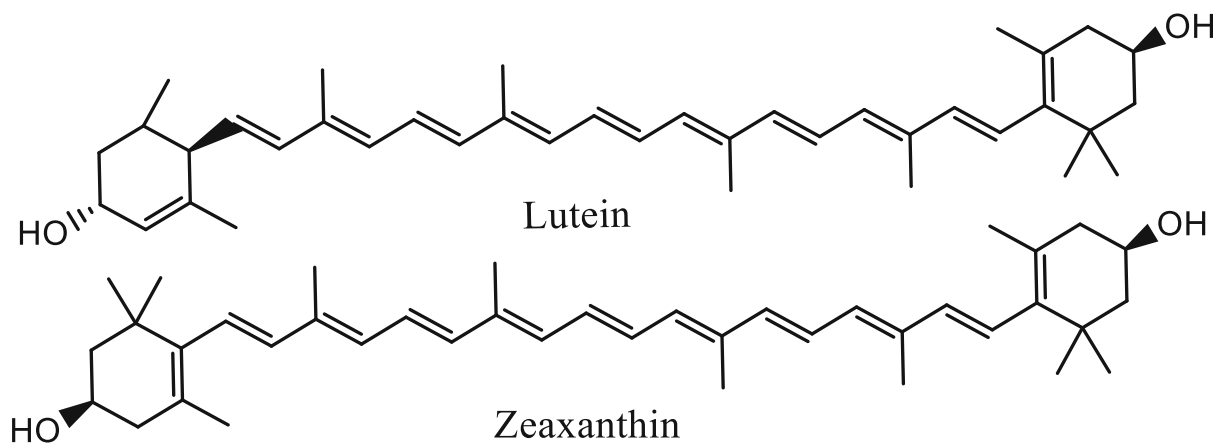

Constituents of avocado

\section{Coconut}

Cocos nucifera $L$. (coconut), belonging to the family Arecaceae, has both nutritional and medicinal properties. Coconut products consist of coconut water, oil, kernels, cake, shell and leaves. Coconut forms an essential part of Indian folk medicine. Coconut water or the liquid endosperm is used as a natural soft drink (Segura-Badilla et al. 2020). Constituents of coconut water include vitamin $\mathrm{B}$, nicotinic acid, pantothenic acid, biotin, sugars, amino acids, vitamin $\mathrm{C}$ and folic acid. Coconut can serve as an electrolyte as it contains adequate levels of potassium, sodium, calcium, magnesium and phosphorus ions (Loomba and Varghese 2013). Tender coconut water can reduce blood pressure. It can act as an antidote also as it helps in the elimination of poisons. The generation of free radicals is reduced due to the presence of amino acid L-arginine. Peroxidation of lipids is decreased due to the presence of vitamin C in water (Prades et al. 2012). Various fatty acids are present in coconut, including caprylic acid, capric acid, lauric acid, myristic acid, palmitic acid, oleic acid, stearic acid and linoleic acid. Coconut water helps in the protection of the heart due to the presence of potassium in it. The density of total cholesterol, triglycerides, LDL and VLDL increases, and the density of HDL elevates by consumption of coconut oil. Coconut oil also exhibits an antithrombotic effect. The concentration of t-PA (tissue plasminogen activator) antigen is lowered by coconut oil rich in saturated fatty acids. Lauric acid and monolaurin are known to kill bacterial species Chlamydia pneumoniae, known for causing atherosclerosis by inducing inflammation resulting in lipoprotein oxidation. L-Arginine is responsible for the hypolipidemic effect, and polyphenols maintain lipid level by inhibiting LDL oxidation, reversing the transport of cholesterol and decreasing absorption of cholesterol in the intestines. Coconut shows an anticholecystitic effect by treating the calculi in kidneys and urethra. Tender coconut water consists of saline and albumin and is used to treat cholera (DebMandal and Mandal 2011). Medium-chain saturated fatty acids are present in coconut oil, and they are easily absorbed and metabolised by the liver (Fernando et al. 2015). They carry out the destruction of lipid-coated bacteria. Coconut oil has bactericidal activity against E. coli, P. aeruginosa, Proteus vulgaris, etc. Besides, it can be used as a skin moisturiser, atopic dermatitis and an antiseptic. Decoction extracted from the roots of the coconut tree can be used as a gargle or mouthwash. Mouth sores can be treated using coconut flour due to the presence of lauric acid.

Sucrose monolaurate, a constituent of coconut, has an anti-caries effect. Coconut oil exhibits antiviral property against Epstein-Barr virus, influenza, leukaemia virus, hepatitis virus, etc. Monolaurin shows antifungal activity against Aspergillus sp., Penicillium sp., C. Albicans, etc. Trichomoniasis can be treated using coconut and can inhibit the growth of Leishmania amazonensis. Coconut kernel protein has an anti-diabetic property by reversing glycogen levels (DebMandal and Mandal 2011). Coconut oil, water and cream may reduce the risk factors such as cholesterol, blood pressure and blood glucose levels associated with Alzheimer's disease. Coconut can enhance the cognition process, which is beneficial for Alzheimer's patients. The antioxidant property is present due to polyphenols such as ferulic acid, caffeic acid, catechin acid and p-coumaric acid. The hydroxyl group present in polyphenols decrease the toxicity of $A \beta$ peptide in Alzheimer's. Trans-zeatin, a component of coconut water, exhibits cell-protective action against toxicity induced by $\mathrm{A} \beta$ plaques. Transzeatin is also an inhibitor of acetylcholinesterase. Figure 5 depicts the role of flavonoids and phenolic compounds in reducing $A \beta$ aggregation and help prevent oxidative stress-mediated Alzheimer's disease (Fernando et al. 2015). 
Fig. 5 Antioxidant activity of coconut oil and mechanism describing how flavonoids can reduce toxicity of Alzheimer's A $\beta$ peptide. The hydroxy groups present in the oil bind to amyloid beta fibrils and hence prevent aggregation
$\mathrm{OH}$ group of phenolic compounds present in coconut oil.

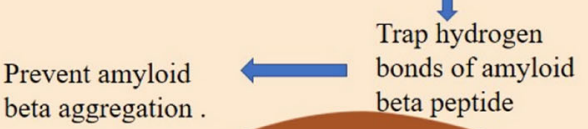

Bind to amyloid beta fibrils.
Prevent amyloid beta aggregation

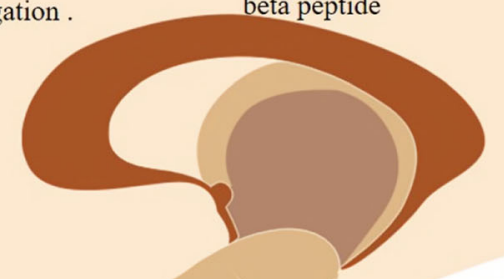<smiles>O=C(O)CCCC[C@@H]1SC[C@@H]2NC(=O)N[C@H]12</smiles>

Biotin<smiles>O=C(O)c1cccnc1</smiles>

Nicotinic Acid<smiles>O=C(O)/C=C/c1ccc(O)cc1</smiles>

p-Coumaric acid<smiles>CC(C)(CO)C(O)C(=O)NCCC(=O)O</smiles>

Pantothenic acid<smiles>CCCCCCCC(=O)O</smiles><smiles>CCCCCCCCCC(=O)O</smiles><smiles>CCCCCCCCCCCC(=O)O</smiles>

Caprylic acid

Lauric acid<smiles>CCCCCCCCCCCCCCCC(=O)O</smiles><smiles>CCCCCCCCCCCCCCCCCC(=O)O</smiles><smiles>CCCCCC=CC=CC=CCCCCC(C)CCCC(=O)O</smiles><smiles>O=C(O)/C=C/c1ccc(O)c(O)c1</smiles><smiles>COc1cc(/C=C/C(=O)O)ccc1O</smiles>

Ferulic acid<smiles>CN(N)CN</smiles>

Catechin

Oleic acid

Caffeic acid

\section{Constituents of coconut}




\section{Broccoli}

Brassica oleracea is a cruciferous vegetable of the mustard family grown from its edible flower buds and stalk. Broccoli is low in calories and a rich source of vitamins and antioxidants (https://www.medicalnewstoday.com/articles/266765). Carcinogenesis can be protected via induction of phase 2 detoxification enzymes such as glutathione transferase, epoxide hydrolase and NADPH (https://www.freshly.com/ blog/articles/broccoli-nutrition-and-health-benefits). Isothiocyanates, present in broccoli, induce phase 2 enzymes. Broccoli sprouts contain increased levels of glucoraphanin and sulforaphane, which are responsible for inducer activity (Fahey et al. 1997). Broccoli sprouts consist of vitamins, carotenoids, minerals and phenolics, and exhibit apoptotic, antibacterial and antioxidant properties. Sprouts possess antiproliferative activity against various carcinomas such as lung carcinoma, hepatocellular carcinoma and colorectal carcinoma. The sprouts show antibacterial activity against Bacillus subtilis, Staphylococcus aureus, Escherichia coli and Salmonella typhimurium. The advantage of using sprouts is that the use of fertilisers and pesticides can be reduced. The sprouts are rich in flavonoids, phenols and vitamin $\mathrm{C}$. The antioxidant activity of broccoli was studied using DPPH (2,2-diphenyl-1-picrylhydrazyl) radical scavenging assay (Le et al. 2019).<smiles>[R]N=C=S</smiles>

Isothiocyanate<smiles>CS(=O)CCCCN=C=S</smiles>

Sulforaphane

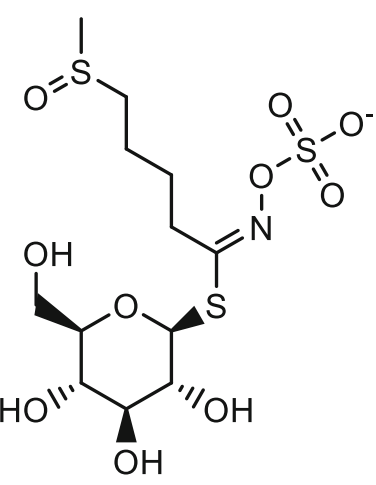

Glucoraphanin

\section{Constituents of broccoli}

\section{Mushroom}

Agaricus campestris is the standard edible part of the fundus of fields and meadows. Mushrooms possess organoleptic properties, medicinal values and a high amount of proteins, fibres, vitamins and minerals. Mushrooms consist of various molecules, including polysaccharides, flavonoids, phenolics, carotenoids, enzymes, alkaloids, volatile oils and terpenoids (Ma et al. 2018). Edible mushrooms are composed of polysaccharide $\beta$-glucans, fibres, peptides, glycoproteins, ascorbic acid etc. Vitamins D2 and B1, iron, selenium and ergothioneine are present in mushrooms. Biologically active constituents are present in fruiting bodies, mycelium and broth of mushrooms. They are also used as a traditional medicine in various countries, including Japan, Russia, Korea and China. They also exhibit various pharmacological actions, including antiviral, antibacterial, antifungal, anti-inflammatory, anti-tumor, hepatoprotective, anti-diabetic, hypolipidemic, antithrombotic actions (Valverde et al. 2015). Oyster mushrooms consist of polysaccharides that possess antihyperlipidemic activity. Proteoglycans present in Agaricus blazei show immunomodulatory and antitumor activity. Polysaccharides present in Agaricus bisporus show activity against breast cancer cells (Cheung 2013). Polysaccharides in Hericium erinaceus exhibit anti-tumor, anti-carcinogenic and antioxidant activities. Lectins or the non-immune proteins have antiproliferative, anti-tumor and immunomodulatory activities. Terpenes or volatile unsaturated hydrocarbons show anti-inflammatory activities. The terpenoids isolated consisted of monoterpenes, sesquiterpenoids, flammulinol, flammulinolides and triterpenoids. These terpenes have a great potential in developing drugs for Alzheimer's disease. Mushrooms also have antioxidant properties as they reduce oxidative damage in human beings. Selenium and zinc are responsible for antioxidant activity. Mushrooms are consumed in dietary supplements, nutraceuticals and medicine, referred to as mushroom pharmaceuticals (Üstün et al. 2018). The major bioactive component of mushroom is $\beta$-glucans. Mushrooms are also a source of prebiotics that alter gastrointestinal tract microbiota activity, providing health benefits to human beings (Friedman 2016).<smiles>OC[C@H]1O[C@H](O[C@@H]2[C@@H](O[C@@H]3[C@@H](CO)O[C@H](O)[C@H](O)[C@H]3O)O[C@H](CO)[C@H](O)[C@H]2O)[C@H](O)[C@@H](O)[C@@H]1O</smiles>

$\beta$-Glucans<smiles>O=C1O[C@H](C(O)CO)C(O)=C1O</smiles>

Ascorbic acid<smiles>C[N+](C)(C)C(Cc1c[nH]c(=S)[nH]1)C(=O)[O-]</smiles>

Ergothioneine

\section{Constituents of mushroom}




\section{Spinach}

Spinacia oleracea (spinach) belongs to the family Chenopodiaceae. It is a rich source of minerals such as iron, copper, zinc, phosphorus, selenium, niacin, folic acid, ascorbic acid, $\beta$-carotene, lutein, flavonoids and omega-3-fatty acids. The presence of tannins, alkaloids, flavonoids, steroids, glycosides and terpenoids impart therapeutic properties to spinach. Spinach is also referred to as a natural anti-ageing wonder. Spinach is a scavenger of reactive oxygen species and helps $\mathrm{n}$ the prevention of oxidative damage. Besides, it is also a rich source of vitamins A, C, E, K, B2 and B6 (https://www. medlife.com/blog/15-reasons-why-spinach-calledsuperfood/). The fatty content in spinach is absent to be consumed easily by obese and diabetic people. Chlorophyll content present in spinach helps in the digestion process. Spinach also has various medicinal properties such as cooling, emollient, diuretic and antipyretic action. Besides, it is used in treating renal calculi, sore throat, joint pain, ringworm scabies and vomiting (https://www.webmd.com/ vitamins/ai/ingredientmono-365/spinach). Flavonoids such as kaempferol, qyricetin, quercetin and luteolin show antidiabetic properties. Spinach provides a hypoglycaemic effect at a dose of 200 and $400 \mathrm{mg} / \mathrm{kg}$. Anti-oxidative and anti-inflammatory properties help in ulcer healing. Glycosides such as coumarins, steroids and flavonoids provide laxative, anti-oxidative and anti-inflammatory properties. Traditionally, spinach has been used for treating joint pains, osteoarthritis and rheumatoid arthritis. Locomotion and balancing activity is improved. Spinach reduces dopamine levels and AchE activities and increases gammaaminobutyric acid (GABA) levels, which help in antischizophrenic activity. Antibacterial activity occurs due to polyphenols para-coumaric acid, ferulic acid and ortho-coumaric acid. Antibacterial activity against gram-negative bacteria is more as compared to grampositive bacteria. Spinach also possesses anti-cancer activity and is used in treating various forms of cancers such as ovarian, prostate and lung cancer (Roughani and Miri 2019).

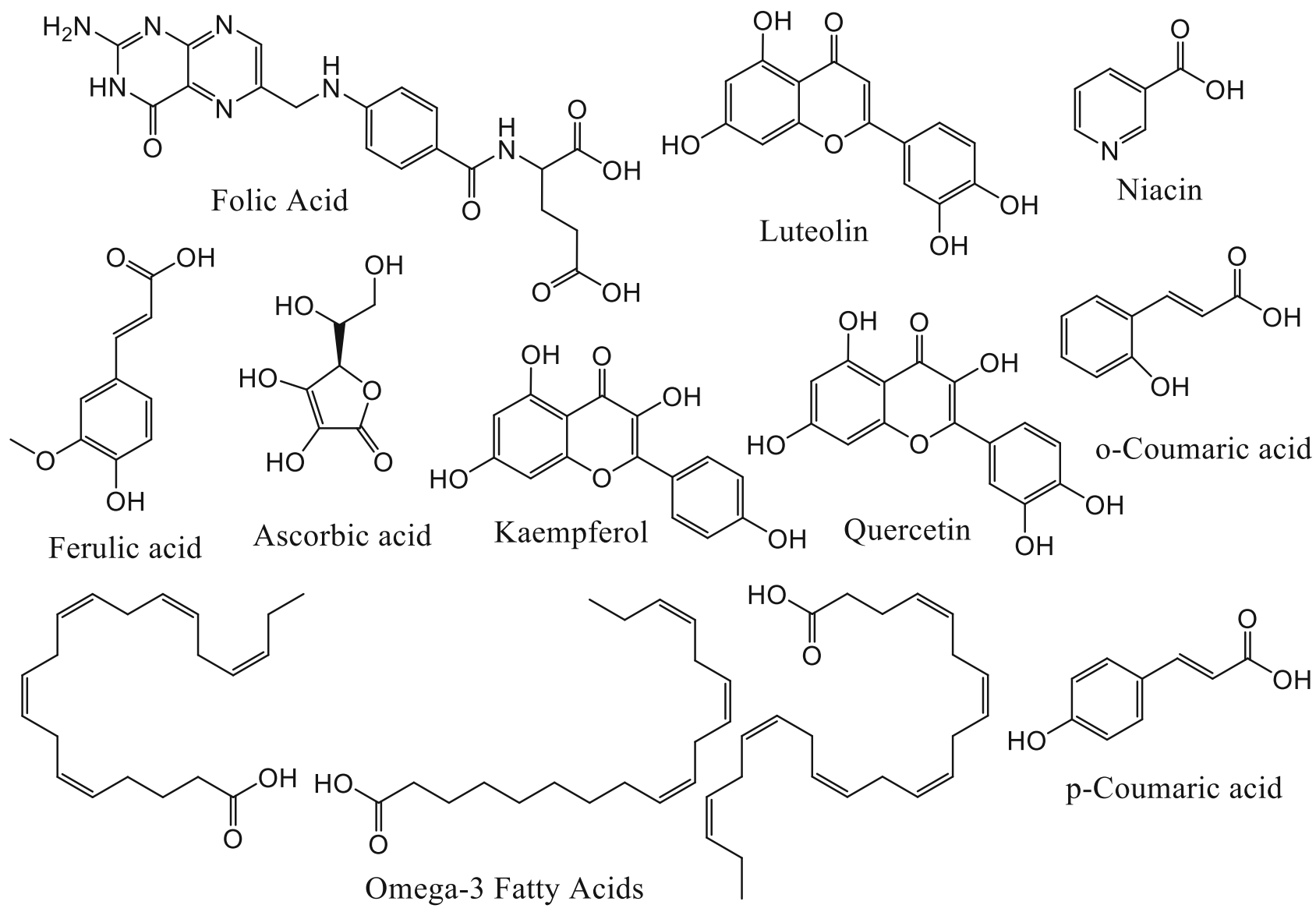

\section{Constituents of spinach}




\section{Pomegranate}

Punica granatum (pomegranate) is a native fruit of the Middle East. Clinical trials have shown the efficacy of pomegranate against diabetes, relief of menopausal symptoms, hormonal balance, cardiovascular disease and prostate cancer (Kandylis and Kokkinomagoulos 2020). High polyphenolic content such as punicalagin, punicalin, gallagic acid and ellagic acid contributes towards its antioxidant activity. Pomegranate is used an as anti-inflammatory, antibacterial, antiviral and antifungal agent. Pomegranate consists of chemical armouries such as anthocyanins and hydrolysable tannins, punicalagin, punicalin, gallagic acid and ellagic acid. Anthocyanins and hydrolysable tannins are present in a significant proportion. Hydrolysable tannins attributed towards an antioxidant activity are measured by Trolox equivalent antioxidant capacity and ascorbic acid equivalent antioxidant capacity (Zarfeshany et al. 2014). The major anthocyanins in pomegranate are delphinidin 3, 5-diglucoside, cyanidin 3,5diglucoside, pelargonidin 3,5-diglucoside, etc. Peel extracts show more antioxidant activity than the juice and seed extracts, which helped prevent lipid peroxidation. High polyphenolic content attributes to high antioxidant activity. The fruit is beneficial in preventing various types of cancers such as breast, colon, skin, cervical and lung cancers. It promotes cardiovascular health by atherosclerosis prevention and managing hyperlipidaemia. Antiviral components extracted from pomegranate when bound to corn starch lead to the development of a topical microbicide, which, when applied topically to the vagina, can inhibit the binding of HIV particles to cell receptors and, hence, prevent infection. The extract obtained from a pomegranate can inhibit the influenza virus, block its replication and inhibit RBCs' aggregation and provide virucidal activity. Punicalagin is responsible for providing antiviral activity (Johanningsmeier and Harris 2011).

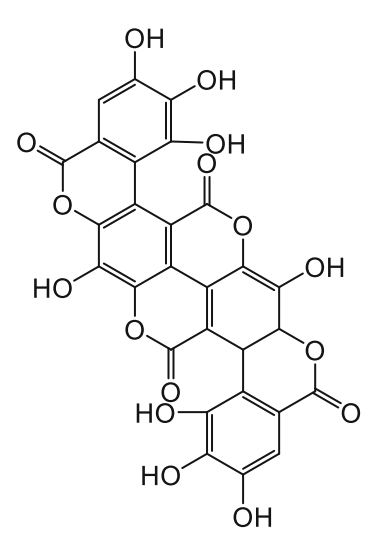

Gallagic acid

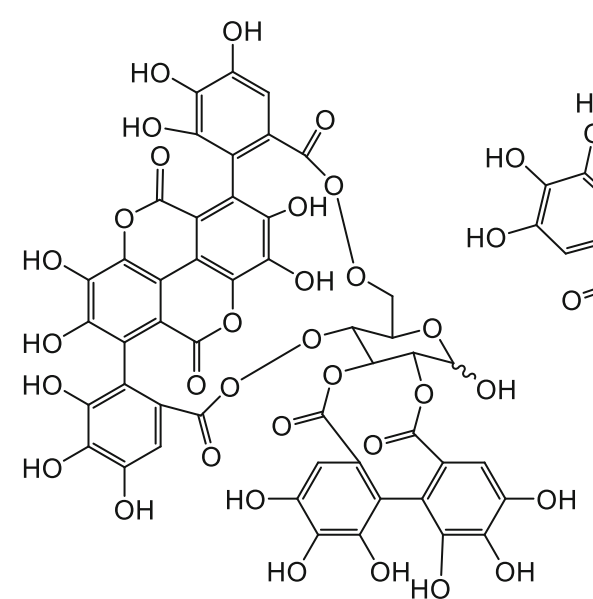

Punicalagin<smiles></smiles>

Cyanidin 3, 5-diglucoside<smiles>[O-]c1cc(O[C@H]2O[C@H](CO)[C@@H](O)[C@H](O)[C+]2O)cc(O[C@@H]2O[C@H](CO)[C@@H](O)[C@H](O)[C@H]2O)c1-c1ccc(O)cc1</smiles>

Pelargonidin 3, 5-diglucoside<smiles>OC[C@H]1O[C@@H](Oc2cc3c(O[C@H]4O[C@H](CO)[C@H](O)[C@H](O)[C@H]4O)cc(O)cc3[o+]c2-c2cc(O)c(O)c(O)c2)[C@H](O)[C@@H](O)[C@@H]1O</smiles>

Delphinidin 3, 5-diglucoside

Constituents of pomegranate

\section{Coriander}

Coriandrum sativum L. (coriander) is a part of the family Apiaceae. It has various medicinal properties and has been traditionally used as folk medicine. Coriander is a rich source of lipids such as petroselinic acid and essential oils such as linalool (Jeet et al. 2020). The most extensively used constituents are the seeds and pericarp, which are composed of essential oils and fatty oils. The oil is a rich source of petroselinic acid. Glycolipids such as acylated steryl glucoside, steryl glucoside 
Table 1 Percentage of essential oils in coriander

S. no. Content of essential oils of coriander Composition of essential oils of coriander $(\%)$

\begin{tabular}{lll} 
1. & Linalool & 37.7 \\
2. & Geranyl acetate & 17.6 \\
3. & Gamma-terpinene & 14.4 \\
4. & Beta-pinene & 1.82 \\
5. & m-Cymene & 1.27 \\
6. & Citronellal & 1.96 \\
7. & Citronellol & 1.31 \\
8. & Citral & 1.36 \\
9. & Geraniol & 1.87 \\
10. & Citronellyl acetate & 1.36 \\
11. & Alpha-cedrene & 3.87 \\
12. & Alpha-farnesence & 1.22 \\
13. & ß-Sesquiphell-andrene & 1.56 \\
\hline
\end{tabular}

and glucocerebroside are present in a significant quantity in seed oil. Coriander oil is an excellent source of tocols such as $\delta$-tocopherol and $\alpha$-tocopherol. Tocotrienol such as $\gamma$ tocotrienol, $\delta$-tocotrienol and $\alpha$-tocotrienol constitute the seed oil. Glucose is the only sugar detected in coriander (Bhat et al. 2014). Essential oils are a source of bioactive. Table 1 represents the various essential oils and their composition (\%) present in coriander. The immature coriander fruits consist of geranyl acetate, linalool, nerol, neral and cis-dihydocarone. The leaves consist of essential oil, flavonoids, phenolic acids and polyphenols. Aldehydes and alcohols are the major constituents of essential oils present in leaves. The main components of a leaf are 2E-tridecen-1-al, 2E-dodecenal, dodecanal, undecanol, undecanal and alkanes. Coriander leaves are used in treating coughs, chest pains and bladder problems. Coriander fruits are used to treat inflammation, bronchitis, cough,

Table 2 Various nutriments and their pharmacological actions

\begin{tabular}{|c|c|c|c|}
\hline $\begin{array}{l}\text { S. } \\
\text { no. }\end{array}$ & Nutriment & Health benefits & References \\
\hline 1. & Flax seeds & $\begin{array}{l}\text { - Reduces cardiovascular diseases } \\
\text { - Decreases cholesterol level } \\
\text { - Prevents diabetes mellitus } \\
\text { - Helps to maintain blood pressure } \\
\text { - Helps in reducing tumor growth }\end{array}$ & Parikh et al. 2019 \\
\hline 2. & Tomato & - Reduces the risk of prostate, lung and belly carcinoma & Giovannucci 1999 \\
\hline 3. & Garlic & $\begin{array}{l}\text { - Reduces total and LDL cholesterol } \\
\text { - Inhibits growth of cancerous cells } \\
\text { - Prevents skin cancer } \\
\text { - Reduces blood pressure } \\
\text { - Inhibits platelet formation in cardiovascular diseases and increased blood flow in the arteries }\end{array}$ & Takezaki et al. 1999 \\
\hline 4. & Yoghurt & $\begin{array}{l}\text { - Reduces symptoms of hypertension and obesity } \\
\text { - Good for gut health }\end{array}$ & $\begin{array}{l}\text { Guiné and De Lemos } \\
2020\end{array}$ \\
\hline 5. & Chocolate & $\begin{array}{l}\text { - Prevents depression, enhances physical and mental functions } \\
\text { - Promotes neurogenesis and improves the function of neurons }\end{array}$ & Erdman et al. 2008 \\
\hline 6. & Nuts & - Improves symptoms in in hypercholesterolemic and diabetic patients. & $\begin{array}{l}\text { Bashan and Bakman } \\
2018\end{array}$ \\
\hline 7. & Cranberries & $\begin{array}{l}\text { - Prevention of urinary tract infections } \\
\text { - Maintains the gut health and oral health } \\
\text { - Maintains epithelial cell health and lowers cholesterol }\end{array}$ & $\begin{array}{l}\text { Coleman and Ferreira } \\
2020\end{array}$ \\
\hline 8. & Black cumin & $\begin{array}{l}\text { - Treats bacterial and fungal infections } \\
\text { - Treats indigestion, diarrhoea, amenorrhoea and dysmenorrhoea } \\
\text { - It also acts as an antiseptic }\end{array}$ & Ahmad et al. 2013 \\
\hline 9. & Avocado & $\begin{array}{l}\text { - Prevents carcinogenesis and inflammation of osteoarthritis } \\
\text { - Maintains skin health. }\end{array}$ & $\begin{array}{l}\text { Dreher and Davenport } \\
2013\end{array}$ \\
\hline 10. & $\begin{array}{l}\text { Cocus } \\
\text { nucifera }\end{array}$ & $\begin{array}{l}\text { - Prevents aggregation of amyloid beta-peptide } \\
\text { - Cures obesity }\end{array}$ & Fernando et al. 2015 \\
\hline 11. & Broccoli & $\begin{array}{l}\text { - Prevents cancer, possesses antiproliferative activity against various carcinomas such as lung carcinoma, } \\
\text { hepatocellular carcinoma and colorectal carcinoma. }\end{array}$ & Le et al. 2019 \\
\hline 12. & Mushroom & $\begin{array}{l}\text { - Antitumor, immunomodulating and hepatoprotective action } \\
\text { - Alters the activity of gastrointestinal tract microbiota providing health benefits to human beings }\end{array}$ & Friedman 2016 \\
\hline 13. & $\begin{array}{l}\text { Spinacia } \\
\quad \text { oleracea }\end{array}$ & $\begin{array}{l}\text { - Reduces risk of age-related macular degeneration } \\
\text { - It also has medicinal properties such as cooling, emollient, diuretic and antipyretic action }\end{array}$ & $\begin{array}{l}\text { Roughani and Miri } \\
2019\end{array}$ \\
\hline 14. & Pomegranate & $\begin{array}{l}\text { - Reduces diabetes } \\
\text { - Helps in prostrate growth } \\
\text { - Promotes cardiovascular health by atherosclerosis prevention and managing hyperlipidaemia }\end{array}$ & $\begin{array}{l}\text { Johanningsmeier and } \\
\text { Harris } 2011\end{array}$ \\
\hline
\end{tabular}


gastrointestinal problems, gout and rheumatism. Coriander is an excellent carminative agent and has antispasmodic actions as well (https:/www.webmd.com/diet/health-benefits-coriander\# 1). Essential oil inhibits gram-positive bacteria such as Staphylococcus aureus; gram-negative bacteria such as Escherichia coli, Pseudomonas aeruginosa and Salmonella typhi; and fungal species like Candida albicans. Flavonoids and polyphenols present in coriander act as antioxidants and are used in the treatment of cancer. Coriander traditionally serves as an anti-diabetic agent. Ethanolic extract of seeds at 200 and $250 \mathrm{mg} / \mathrm{kg}$ decreases serum glucose concentration and increases $\beta$-cell activity. The seeds show a lipid-lowering effect by decreasing triglycerides, LDL, VLDL levels and increasing HDL levels. It diminishes the activity of the enzyme HMG$\mathrm{CoA}$ reductase. Coriander has been traditionally used in Iran as an anticonvulsant and anti-depressant. Coriander juice has been known to decrease the mutagenicity of aromatic amines. Coriander is used as a diuretic to treat acute renal failure by enhancing renal salt and water excretion (Sahib et al. 2013). Dodecanal, an antibacterial agent present in coriander leaf, helps fight Salmonella (species causing foodborne illness). Miscellaneous uses of coriander include treating mouth ulcers, anaemia, menstrual disorders, eye disorders, smallpox and skin disorders (Beemnet 2020) (Table 2).

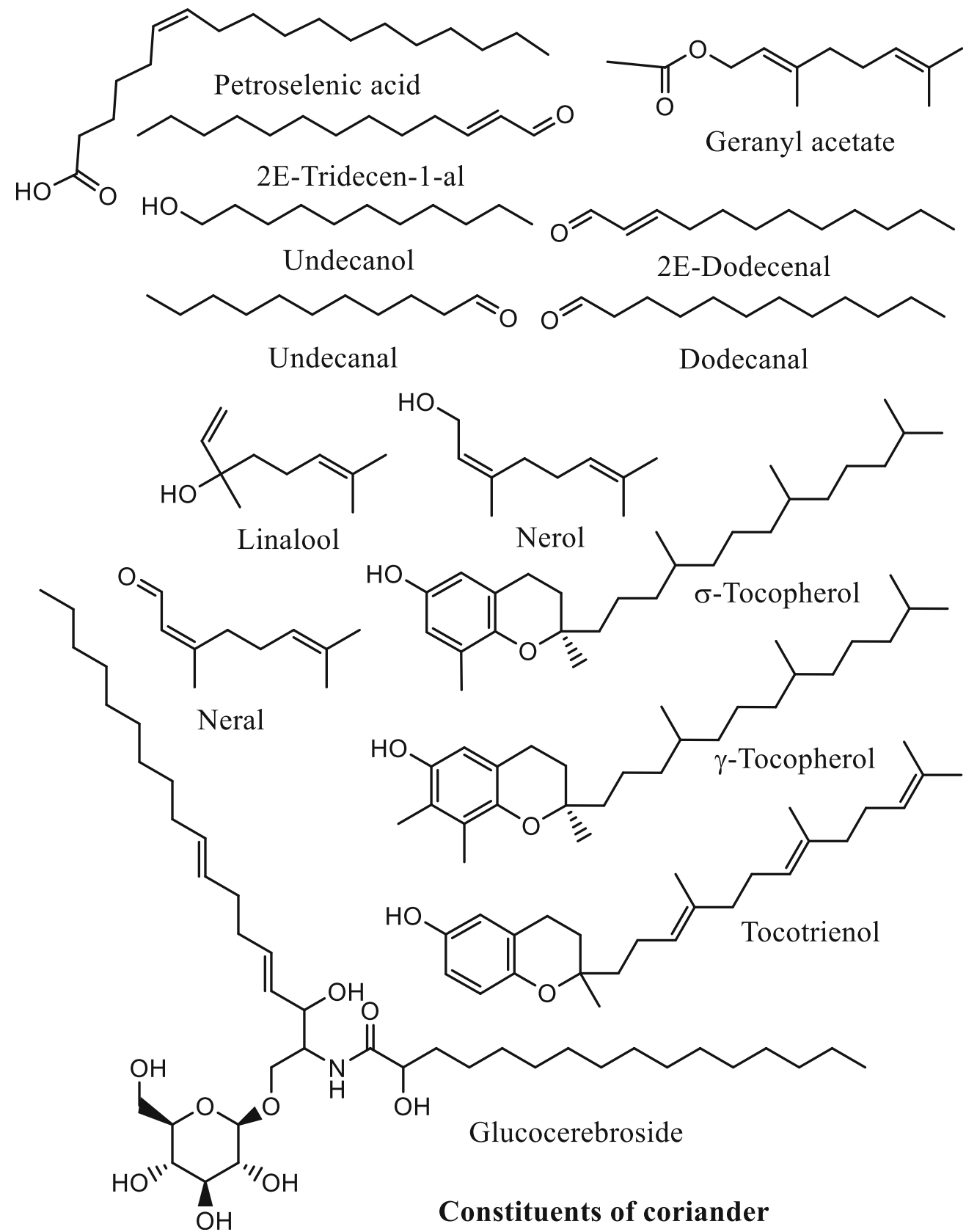




\section{Marketed preparations and clinical status of nutriments}

Making people more aware of nutraceuticals' benefits can expand the functional food market. Scientific research can be expanded for more effective and safe products. New technologies such as nutrigenomics, imaging techniques and converging technologies can be introduced in the research field (Daliri and Lee 2015). Nutrigenomics is an emerging field which defines the role of nutrition on gene expression involving the science of bioinformatics, molecular biology, nutrition, proteomics and genomics. The concept of nutrigenomics is being followed highly in USA and UK; however, India is still lacking behind and more research into the field is required. Nutrigenomics is being widely studied in heart diseases, cancers, diabetes, male infertility and disorders related to diet (Neeha and Kinth 2013). The metabolomics field can be applied in discovering novel biomarkers of food intake as the foods contain various metabolites which enter the body fluids after the digestion process and hence can be detected using targeted and untargeted metabolomics approaches. For example, the putative biomarkers for raspberries are caffeic acid-sulphate and methylepicatechin-sulphate whereas for chocolate are 6-amino-5-(N-methylformylamino)-1methyluracil, theobromine and 7-methyl-uric acid.
Developments in stem cell biology pave the way for model development in nutrigenomics research (Mathers 2017).

Table 3 depicts the chemical constituents, uses and marketed products available for the various essential nutriments, and Table 4 represents the clinical status of various nutriments undergoing trials whose studies have been completed ((https://www.clinicaltrials.gov/).

\section{Future perspective}

The challenges to achieving feasibility in the field of nutriments are disconcerting. Consumers are increasingly becoming aware of the nutritional benefits of disease prevention. Various studies such as European Commissionfunded projects have made it possible to understand essential mechanisms of biologically active compounds present in functional foods. Increasing demand for these nutraceuticals has diversified the field of agriculture and promotes research in these particular areas. The challenges faced by the nutraceutical markets are the regulations of specific countries and health claim substantiation. Increasing health care costs propel the nutraceutical' market. Market revenues can be increased by more investment in new technology and applying genetically modified techniques.

Table 3 Marketed preparations of nutriments

\begin{tabular}{|c|c|c|c|c|}
\hline S. no. & Name & Chemical constituents & Marketed preparations & Uses \\
\hline 1. & Flaxseeds & Linolenic acid & Healthvit flaxseed oil softgels & $\begin{array}{l}\text { - Maintains normal blood sugar level } \\
\text { - Reduces tenderness in joints } \\
\text { - Maintains heart health }\end{array}$ \\
\hline 2. & Tomato & Lycopene & Healthyhey lycopene capsules & $\begin{array}{l}\text { - It helps in promoting prostate health } \\
\text { - Antioxidant }\end{array}$ \\
\hline 3. & Garlic & Allicin & Nutra high allicin garlic enteric-coated supplements & - Improves cardio, immune and enzyme health \\
\hline 4. & Yoghurt & Linolenic acid & Mother dairy yoghurt & $\begin{array}{l}\text { - Strengthens immune system } \\
\text { - Protects against osteoporosis }\end{array}$ \\
\hline 5. & Chocolate & Theobromine & Zevic $70 \%$ dark Belgian chocolate & $\begin{array}{l}\text { - Good for concentration } \\
\text { - Diabetic patients }\end{array}$ \\
\hline 6. & Cranberries & Proanthrocyanidins & Pure nutrition cranberry plus & $\begin{array}{l}\text { - Helps to prevent urinary tract infection } \\
\text { - Prevents the formation of kidney crystals } \\
\text { - Boosts immunity }\end{array}$ \\
\hline 7. & Black Cumin & Thymoquinone & Mahaved black seed extract capsules & $\begin{array}{l}\text { - Lowers cholesterol } \\
\text { - Improves asthma }\end{array}$ \\
\hline 8. & Avocado & Lutein and Zeaxanthin & Healthy hey nutrition lutein and zeaxanthin capsules & $\begin{array}{l}\text { - Improves eye health } \\
\text { - Improves skin health }\end{array}$ \\
\hline 9. & Coconut & Pantothenic acid & Zenith nutrition capsules & $\begin{array}{l}\text { - Helps build stamina } \\
\text { - Stimulates hormones } \\
\text { - Promotes good skin health }\end{array}$ \\
\hline 10. & Broccoli & Sulforaphane & Vitrovea greens powder & $\begin{array}{l}\text { - Antibacterial } \\
\text { - Detox body }\end{array}$ \\
\hline 11. & Pomegranate & Ellagic acid & Healthvit pomegranate capsules & $\begin{array}{l}\text { - Aids digestion } \\
\text { - Boosts immune health } \\
\text { - Promotes healthy skin and hair }\end{array}$ \\
\hline
\end{tabular}


Table 4 Description of clinical studies for various essential nutriments

Condition/disease

Treatment

Status

\begin{tabular}{ll}
\hline Identifier & Title of the study \\
\hline NCT02324439 & $\begin{array}{l}\text { Flaxseed as Maintenance Therapy for Ovarian Cancer } \\
\text { Patients in Remission }\end{array}$ \\
NCT02047123 & $\begin{array}{l}\text { Nutritional Intervention WithYoghurt and Flaxseed in } \\
\text { Women With Profiles Lipi (flaxseed) }\end{array}$ \\
NCT02014181 & $\begin{array}{c}\text { Flaxseed Modulates Inflammation and Oxidative Stress in } \\
\text { CF }\end{array}$ \\
NCT03713138 & $\begin{array}{c}\text { Therapeutic Role of Flax Seed for Poly Cystic Ovary } \\
\text { Syndrome }\end{array}$
\end{tabular}

NCT01698112 Does Flaxseed Supplementation Improve Glycemic Control in Individuals With Pre-diabetes?

NCT00937742 The Effect of Processed Tomato Products on CVD Risks (TOMATO)

NCT02292524 Prostate Biomarkers in Men Consuming Tomato Products

NCT01665469 Effect of Tomato Extracted Lycopene on Postprandial Oxidation and inflammation in Healthy Weight Men and Women

NCT03617068 The Effectiveness of Coconut Oil Cream as a Prevention Treatment for Occupational Hand Dermatitis Among Batik Workers

NCT03354299 Effect of Coconut Milk Supplementation to Improve Nutritional Status in Cirrhosis Patient

- Epithelial ovarian cancer

- Fallopian tube cancer

- Primary peritoneal cancer

Overweight

- Cystic fibrosis

- Oxidative stress

- Inflammation

Polycystic ovary syndrome

Prediabetes

Cardiovascular disease

Prostate cancer

Postprandial oxidation and inflammation

Hand dermatoses

- Malnutrition

- Cirrhosis, liver

- Obesity

- Cardiovascular risk factor Consumption of Coconut Flour in Women With Overweight

NCT03931434 Effect of Aged Garlic Extract (AGE) on Improving Coronary Atherosclerosis in People With Type 2 Diabetes Mellitus

- Coronary

arteriosclerosis

- Endothelial dysfunction

- Type 2 diabetes mellitus

NCT01534910 Effect of Aged Garlic Extract on Atherosclerosis (Garlic4)

NCT00200785 Identifying the Anti-Blood-Clotting Compounds in Garlic

NCT03926806 Yoghurt Consumption, Body Weight Management and Glycemic Control of T2DM Patients

NCT02629341 Functional Yoghurt Powder Effect on Bone Health Biomarkers

(bonefoods)

NCT02494739 Antioxidant and Anti-inflammatory Effects of Yoghurt Enriched With Polyphenols

NCT03326934 Impact of Dark Chocolate on Visual Performance

NCT02130141 The Effects of Dark Chocolate on Blood Pressure in Individuals With Mildly Elevated Blood Pressure (CHOKO)

NCT01431443 Consumption of Chocolate in Pregnant Women. (CHOCENTA)

NCT03680027 Effects Of Walnut-Enriched Diet On Blood Lipids And Glucose Profiles In Hyperlipidemic Subjects

NCT00901043 Effects of Walnut Consumption on Endothelial Function in Diabetes mellitus type 2 Type 2 Diabetes (WALNUT)

NCT02764749 Cranberry (Poly)Phenol Consumption on Vascular Function Healthy young

NCT03042273 High Strength Cranberry Supplementation for Prevention of Urinary tract infection Recurrent Urinary Tract Infection

NCT02556749 Effects of Cranberry Juice on Cardiovascular Risk Factors

NCT01531062 Effect of Nigella Sativa on Lipid Profiles in Elderly
Metabolic syndrome

- Arteriosclerosis

- Intracranial arteriosclerosis

Type 2 diabetes mellitus

Osteopenia

- Oxidative stress

- Inflammation

Dietary supplementation

Blood pressure

Preeclampsia

Hyperlipidemias

Cardiovascular disease risk factors

Dyslipidemia
Omega nutrition cold-milled flaxseeds

Phase 1

Raw flaxseed

Not applicable

Finely ground flaxseed powder

Flaxseed powder

Not applicable

Flaxseed

Not applicable

Tomato products

Not applicable

Commercially available tomato food product

Tomato extracted lycopene

Cocos Nucifera Whole

Phase 3

Coconut milk

Not applicable

Coconut flour

Not applicable

Aged garlic extract (AGE)

Not applicable

Aged garlic extract

Garlic powder added to ambient water and boiling water

Plain yoghurt and vitamin Not applicable B yoghurt

Functional yoghurt powder and control yoghurt powder

Yoghurt

Dark chocolate

Dark chocolate

Phase 3

Not applicable

Not applicable

Not applicable

Flavanol-rich chocolate

Phase 2

Walnut-enriched Group Not applicable

Walnut supplementation Not applicable

Cranberry (poly)phenol Not applicable containing supplement

High strength cranberry Phase 2

Cranberry juice beverage Not applicable

Nigella sativa

Phase 2 
Table 4 (continued)

\begin{tabular}{|c|c|c|c|c|}
\hline Identifier & Title of the study & Condition/disease & Treatment & Status \\
\hline NCT04347382 & $\begin{array}{l}\text { Honey \& Nigella Sativa Trial Against COVID-19 } \\
\text { (HNS-COVID-PK) }\end{array}$ & Coronavirus infection & $\begin{array}{l}\text { Nigella sativa/black } \\
\text { cumin and honey }\end{array}$ & Phase 3 \\
\hline NCT01235832 & $\begin{array}{l}\text { The Effect of Avocado on Cardiovascular Disease (CVD) } \\
\text { Risk Factors }\end{array}$ & $\begin{array}{l}\text { - Cardiovascular disease } \\
\text { - Hyperlipidemia }\end{array}$ & Avocado diet & Not applicable \\
\hline NCT01929564 & Broccoli and Vascular Health Study (BASH) & Cardiovascular diseases & $\begin{array}{l}\text { Beneforte broccoli and } \\
\text { Parthenon broccoli }\end{array}$ & Not applicable \\
\hline NCT00994604 & $\begin{array}{l}\text { The Effects of Broccoli Sprout Extract on Obstructive Lung } \\
\text { Disease }\end{array}$ & $\begin{array}{l}\text { - Asthma } \\
\text { - COPD }\end{array}$ & Broccoli sprout extract & Not applicable \\
\hline NCT01398176 & Immune Benefits From Mushroom Consumption & Healthy humans & Mushrooms & Not applicable \\
\hline NCT01815437 & Evaluating Vitamin D Content in Mushrooms & Vitamin D deficiency & Mushroom vitamin D2 & Not applicable \\
\hline NCT02093130 & Study of Pomegranate Juice on Memory in Older Adults & Memory & Pomegranate juice & Phase 2 \\
\hline NCT03902288 & $\begin{array}{l}\text { Short-term Effect of Pomegranate Juice on Blood Sugar and } \\
\text { Its Controlling Hormones in Pre-diabetic and Type II } \\
\text { Diabetic Patients. }\end{array}$ & $\begin{array}{l}\text { Patients with type } 2 \\
\text { diabetes }\end{array}$ & Fresh pomegranate juice & Not applicable \\
\hline
\end{tabular}

\section{Conclusion}

As discussed, nutriments are essential diet supplements that can cure the symptoms of specific diseases and are therapeutically active foods. Based on their cost-effectiveness, easy availability and convenient cultivating procedures, specific nutriments were selected for this review. These nutriments are available in almost every region and are consumed by people of all classes daily. They can be added to the daily lifestyle and can lead to a new era in medicine and health. Nutraceuticals cover a wide range of therapeutic areas such as anti-inflammatory, anti-carcinogenic, anti-hypertensive, anti-hyperlipidemic, antioxidants, anti-and hyperglycemic. The antioxidant defence mechanism of the body deprives with the growing age, and nutraceuticals may pave the way for treating disorders occurring due to this oxidative stress. More research work is going on and is at the peak for the rising nutraceutical field. Hence, it can be concluded that nutriments can provide proven health benefits. Their intake can be beneficial in a natural form and maintain overall human health.

Author contribution Conceptualization, R. K. and T. B.; writingoriginal draft preparation, A. S. and M. K.; literature review: S. A., S. B., and A. A. H.; writing - review and editing, T. B. and L. A.

Data availability Not applicable.

\section{Declarations}

Ethical approval Not applicable.

Consent to participate Not applicable.
Consent to publish All the authors have approved the manuscript for publication.

Competing interests The authors declare no competing interests.

\section{References}

Ahmad A, Husain A, Mujeeb M, Khan SA, Najmi AK, Siddique NA, Damanhouri ZA, Anwar F (2013) May 1. A review on therapeutic potential of Nigella sativa: a miracle herb. Asian Pac J Trop Biomed 3(5):337-352. https://doi.org/10.1016/S2221-1691(13)60075-1

Alkhalaf MI, Alansari WS, Ibrahim EA, ELhalwagy ME (2019) Antioxidant, anti-inflammatory and anti-cancer activities of avocado (Persea americana) fruit and seed extract. J King Saud Univ Sci 31(4):1358-1362. https://doi.org/10.1016/j.jksus.2018.10.010

Arai S (1996) Studies on functional foods in Japan - state of the art. Biosci Biotechnol Biochem 60(1):9-15. https://doi.org/10.1271/ bbb.60.9

Astrup A (2014) Yogurt and dairy product consumption to prevent cardiometabolic diseases: epidemiologic and experimental studies. Am J Clin Nutr 99(5):1235S-1242S. https://doi.org/10.3945/ajen.113. 073015

Bashan İ, Bakman M (2018) The effect of daily walnut consumption on dyslipidemia. J Food Qual 2018:1-6. https://doi.org/10.1155/2018/ 4731826

Bayan L, Koulivand PH, Gorji A (2014) Garlic: a review of potential therapeutic effects. Avicenna J Phytomed 4(1):1-14

Beemnet MK (2020) Unleashing the exploitation of coriander (Coriander sativum L.) for biological, industrial and pharmaceutical applications. Acad Res J Agri Sci Res 8(6):552-564. https://doi.org/10. 14662/ARJASR2020.555

Bhat S, Kaushal P, Kaur M, Sharma HK (2014) Coriander (Coriandrum sativum L.): processing, nutritional and functional aspects. African J Plant Sci 8(1):25-33

Block E (2004) Biological activity of Allium compounds: recent results. In: IV International Symposium on Edible Alliaceae 688, pp 41-58. https://doi.org/10.17660/ActaHortic.2005.688.4

Blumberg JB, Camesano TA, Cassidy A, Kris-Etherton P, Howell A, Manach C, Ostertag LM, Sies H, Skulas-Ray A, Vita JA (2013) 
Cranberries and their bioactive constituents in human health. Adv Nutr 4(6):618-632

Cheung PC (2013) Mini-review on edible mushrooms as source of dietary fiber: preparation and health benefits. Food Sci Human Wellness 2(3-4):162-166

Chishty S, Bissu M (2016) Health benefits and nutritional value of flaxseed-a review. Indian J Appl Res 6(1):243-245

Clinton SK (1998) Lycopene: chemistry, biology, and implications for human health and disease. Nutr Rev 56(2 Pt 1):35-51. https://doi. org/10.1111/j.1753-4887.1998.tb01691.x

Coleman CM, Ferreira D (2020) Oligosaccharides and complex carbohydrates: a new paradigm for cranberry bioactivity. Molecules 4:881. https://doi.org/10.3390/molecules25040881

Daliri EB, Lee BH. (2015) Current trends and future perspectives on functional foods and nutraceuticals. In: Beneficial microorganisms in food and nutraceuticals. Springer, Cham, pp 221-244. https://doi. org/10.1007/978-3-319-23177-8 10

Das L, Bhaumik E, Raychaudhuri U, Chakraborty R (2012) Role of nutraceuticals in human health. J Food Sci Technol 49(2):173183. https://doi.org/10.1007/s13197-011-0269-4

DebMandal M, Mandal S (2011) Coconut (Cocos nucifera L.: Arecaceae): in health promotion and disease prevention. Asian Pac J Trop Med 4(3):241-247. https://doi.org/10.1016/S1995-7645(11) 60078-3

Dreher ML, Davenport AJ (2013) Hass avocado composition and potential health effects. Crit Rev Food Sci Nutr 53(7):738-750. https:// doi.org/10.1080/10408398.2011.556759

Erdman JW Jr, Carson L, Kwik-Uribe C, Evans EM, Allen RR (2008) Effects of cocoa flavanols on risk factors for cardiovascular disease. Asia Pac J Clin Nutr Suppl 1:284-287

Fahey JW, Zhang Y, Talalay P (1997) Broccoli sprouts: an exceptionally rich source of inducers of enzymes that protect against chemical carcinogens.Proc. Natl Acad Sci 94(19):10367-10372. https://doi. org/10.1073/pnas.94.19.10367

Fan XY, Lin WP, Rui LI, Jiang NH, Cai KZ (2018) Physiological response and phenolic metabolism in tomato (Solanum lycopersicum) mediated by silicon under Ralstonia solanacearum infection. J Integr Agric 17(10):2160-2171. https://doi.org/10.1016/S2095-3119(18) 62036-2

Farhat G, Drummond S, Fyfe L, Al-Dujaili EA (2014) Dark chocolate: an obesity paradox or a culprit for weight gain? Phytother Res 28(6): 791-797

Feldman EB (2002) The scientific evidence for a beneficial health relationship between walnuts and coronary heart disease. J Nutr 2(5): 1062S-1101S. https://doi.org/10.1093/jn/132.5.1062S

Fernando WM, Martins IJ, Goozee KG, Brennan CS, Jayasena V, Martins RN (2015) The role of dietary coconut for the prevention and treatment of Alzheimer's disease: potential mechanisms of action. Br J Nutr 114(1):1-4. https://doi.org/10.1017/ S0007114515001452

Friedman M (2016) Mushroom polysaccharides: chemistry and antiobesity, antidiabetes, anticancer, and antibiotic properties in cells, rodents, and humans. Foods 5(4):80. https://doi.org/10.3390/ foods 5040080

Gardana C, Scialpi A, Fachechi C, Simonetti P (2020) Identification of markers for the authentication of cranberry extract and cranberrybased food supplements. Heliyon 6(4):e03863. https://doi.org/10. 1016/j.heliyon.2020.e03863

Giovannucci E (1999) Tomatoes, tomato-based products, lycopene, and cancer: review of the epidemiologic literature. J Natl Cancer Inst 91(4):317-331. https://doi.org/10.1093/jnci/91.4.317

Goyal A, Sharma V, Upadhyay N, Gill S, Sihag M (2014) Flax and flaxseed oil: an ancient medicine \& modern functional food. J Food Sci Technol 51(9):1633-1653. https://doi.org/10.1007/ s13197-013-1247-9
Guiné RP, De Lemos ET (2020) Development of new dairy products with functional ingredients. J Culin Sci Technol 18(3):159-176. https:// doi.org/10.1080/15428052.2018.1552901

Haghighatsiar N, Askari G, Saraf-Bank S, Keshmiri AFH (2019) Effect of flaxseed powder on cardiovascular risk factor in dyslipidemic and hypertensive patients. Int J Prev Med. https://doi.org/10.4103/ijpvm. IJPVM_563_17

Haidari F, Banaei-Jahromi N, Zakerkish M, Ahmadi K (2020) The effects of flaxseed supplementation on metabolic status in women with polycystic ovary syndrome: a randomized open-labeled controlled clinical trial. Nutr J 19(1):1-1

Halib H, Ismail A, Mohd Yusof BN, Osakabe N, Mat Daud ZA (2020) Effects of cocoa polyphenols and dark chocolate on obese adults: a scoping review. Nutrients. 12(12):3695

Hisano M, Bruschini H, Nicodemo AC, Srougi M (2012) Cranberries and lower urinary tract infection prevention. Clinics. 67(6):661-668. https://doi.org/10.6061/clinics/2012(06)18

Jeet K, Malaviya A, Baldi A (2020) Productivity enhancement of coriandrum sativum using plant biologicals. Int J Pharm Pharm Sci 12(5):60-72

Johanningsmeier SD, Harris GK (2011) Pomegranate as a functional food and nutraceutical source. Annu Rev Food Sci Technol 2:181-201. https://doi.org/10.1146/annurev-food-030810-153709

Kajla P, Sharma A, Sood DR (2015) Flaxseed - a potential functional food source. J Food Sci Technol 52(4):1857-1871. https://doi.org/ 10.1007/s13197-014-1293-y

Kandylis P, Kokkinomagoulos E (2020) Food applications and potential health benefits of pomegranate and its derivatives. Foods 9(2):122. https://doi.org/10.3390/foods9020122

Khramtsov AG, Ryabtseva SA, Budkevich RO, Akhmedova VR, Rodnaya AB, Marugina EV (2017) Prebiotics as functional food ingredients: terminology, choice and comparative evaluation criteria, classification. Vopr Pitan 87(1):5-17

Le TN, Luong HQ, Li HP, Chiu CH, Hsieh PC (2019) Broccoli (Brassica oleracea L. var. italica) sprouts as the potential food source for bioactive properties: a comprehensive study on in vitro disease models. Foods 8(11):532. https://doi.org/10.3390/foods8110532

Loomba S, Varghese JM (2013) Cocos Nucifera: its properties and contributions to dentistry. Int J Sci Study 1(3):138-140

Ma G, Yang W, Zhao L, Pei F, Fang D, Hu Q (2018) A critical review on the health promoting effects of mushrooms nutraceuticals. Food Sci Human Wellness 7(2):125-133. https://doi.org/10.1016/j.fshw. 2018.05 .002

Mathers JC (2017) Nutrigenomics in the modern era. Proc Nutr Soc 76(3):265-275

Mestry M, Bajaj A, Rane M, Lalan K (2016) Herbal CNS stimulants. Int J Herb Med 4(6):109-116

Neeha VS, Kinth P (2013) Nutrigenomics research: a review. J Food Sci Technol 50(3):415-428

Nowak DA, Snyder DC, Brown AJ, Demark-Wahnefried W (2007) The effect of flaxseed supplementation on hormonal levels associated with polycystic ovarian syndrome: a case study. Curr Top Nutraceutical Res 5(4):177-181. https://doi.org/10.1016/j.fshw. 2013.08.001

Ortega R (2006) Importance of functional foods in the Mediterranean diet. Public Health Nutr 9(8A):1136-1140. https://doi.org/10. $1017 / \mathrm{S} 1368980007668530$

Pagliai G, Sofi F, Vannetti F, Caiani S, Pasquini G, Molino Lova R, Cecchi F, Sorbi S, Macchi C (2018) Mediterranean diet, food consumption and risk of late-life depression: the Mugello Study. J Nutr Health Aging 22(5):569-574. https://doi.org/10.1007/s12603-0181019-3

Parikh M, Maddaford TG, Austria JA, Aliani M, Netticadan T, Pierce GN (2019) Dietary flaxseed as a strategy for improving human health. Nutrients 11(5):1171. https://doi.org/10.3390/nu11051171 
Park YW (ed) (2009) Bioactive components in milk and dairy products. Wiley, Hoboken. https://doi.org/10.1002/9780813821504

Pise AG, Pise S, Sreedhar D, Manthan J, Ligade VS, Udupa N (2009) Garlic: a wonder nutraceutical. Int J Curr Res Rev 1(2):44-51

Prades A, Dornier M, Diop N, Pain JP (2012) Coconut water uses, composition and properties: a review. Fruits. 67(2):87-107. https://doi. org/10.1051/fruits/2012002

Rachman PN, Darmawan E.(2017) The efficacy of black cumin seed (Nigella sativa) oil and hypoglycemic drug combination to reduce $\mathrm{HbA} 1 \mathrm{c}$ level in patients with metabolic syndrome risk. In: IOP Conference Series: Materials Science and Engineering, vol 259, No. 1. IOP Publishing, Bristol, p 012018. https://doi.org/10.1088/ 1757-899X/259/1/012018

Rahmani AH, Aly SM (2015) Nigella sativa and its active constituent's thymoquinone shows pivotal role in the diseases prevention and treatment. Asian J Pharm Clin Res 8(1):48-53

Rajasekaran A, Sivagnanam G, Xavier R (2008) Nutraceuticals as therapeutic agents: a review. Res J Pharm Tech. https://doi.org/10.5958/ 0974-360X

Roughani A, Miri SM. (2019) Spinach: An important green leafy vegetable and medicinal herb. In: The 2nd International Conference on Medicinal Plants, Organic Farming, Natural and Pharmaceutical Ingredients, pp 1-6. https://doi.org/10.21767/2321-2748.100344

Sahib NG, Anwar F, Gilani AH, Hamid AA, Saari N, Alkharfy KM (2013) Coriander (Coriandrum sativum L.): a potential source of high-value components for functional foods and nutraceuticals-A review. Phytother Res 27(10):1439-1456. https://doi.org/10.1002/ ptr.4897

Segura-Badilla O, Lazcano-Hernández M, Kammar-García A, VeraLópez O, Aguilar-Alonso P, Ramírez-Calixto J, Navarro-Cruz AR (2020) Use of coconut water (Cocus nucifera L) for the development of a symbiotic functional drink. Heliyon 6(3):e03653. https://doi. org/10.1016/j.heliyon.2020.e03653

Smith DF (2013) Benefits of flavanol-rich cocoa-derived products for mental well-being: A review. J Funct Foods 5(1). https://doi.org/ 10.1089/ars.2010.3697

Stevinson C, Pittler MH, Ernst E (2000) Garlic for treating hypercholesterolemia. A meta-analysis of randomized clinical trials. Ann Intern Med 133(6):420-429. https://doi.org/10.7326/0003-4819-133-6200009190-00009
Story EN, Kopec RE, Schwartz SJ, Harris GK (2010) An update on the health effects of tomato lycopene. Annu Rev Food Sci Technol 1: 189-210. https://doi.org/10.1146/annurev.food.102308.124120

Suleria HA, Butt MS, Khalid N, Sultan S, Raza A, Aleem M, Abbas M (2015) Garlic (Allium sativum): diet based therapy of 21st century-a review. Asian Pac J Trop Dis 5(4):271-278. https://doi.org/10.1016/ S2222-1808(14)60782-9

Takezaki T, Gao CM, Ding JH, Liu TK, Li MS, Tajima K (1999) Comparative study of lifestyles of residents in high and low risk areas for gastric cancer in Jiangsu Province, China; with special reference to allium vegetables. J Epidemiol 9(5):297-305. https:// doi.org/10.2188/jea.9.297

Thomson C, Bloch AS, Hasler CM, Kubena K, Earl R, Heins J (1999) Position of the American Dietetic Association: functional foods. J Am Diet Assoc 99(10):1278-1285. https://doi.org/10.1016/S00028223(99)00314-4

Üstün NŞ, Bulam S, Pekșen A.(2018) The use of mushrooms and their extracts and compounds in functional foods and nutraceuticals. Türkmen A (ed) 1:1205-22. https://doi.org/10.24925/turjaf.v7isp1. 94-100.2729

Valverde ME, Hernández-Pérez T, Paredes-López O (2015) Edible mushrooms: improving human health and promoting quality life. Int J Microbiol 2015:376387. https://doi.org/10.1155/2015/376387

Wan Y, Vinson JA, Etherton TD, Proch J, Lazarus SA, Kris-Etherton PM (2001) Effects of cocoa powder and dark chocolate on LDL oxidative susceptibility and prostaglandin concentrations in humans. Am J Clin Nutr 74(5):596-602. https://doi.org/10.1089/ars.2010.3697

Wei MY, Giovannucci EL (2012) Lycopene, tomato products, and prostate cancer incidence: a review and reassessment in the PSA screening era. J Oncol 2012:1-7. https://doi.org/10.1155/2012/271063

Whitman M (2001) Understanding the perceived need for complementary and alternative nutraceuticals: lifestyle issues. Clin J Oncol Nurs 5:190-194

Zarfeshany A, Asgary S, Javanmard SH (2014) Potent health effects of pomegranate. Adv Biomed Res 3:100. https://doi.org/10.4103/ 2277-9175.129371

Zeisel SH (1999) Regulation of "nutraceuticals". Science 285(5435): 1853-1855. https://doi.org/10.1126/science.285.5435.1853

Publisher's note Springer Nature remains neutral with regard to jurisdictional claims in published maps and institutional affiliations. 